\title{
Observation of feeding habit of the Asian water monitor, Varanus salvator (Laurenti, 1768) (Squamata Varanidae) on a Asian toad, Duttaphrynus melanostictus (Schneider, 1799) (Anura Bufonidae) in Thailand
}

\author{
Rujira Mahaprom ${ }^{1,2} \&$ Sitthi Kulabtong ${ }^{1 *}$ \\ ${ }^{1}$ Save wildlife Thailand, Wangnoi District, Ayuttaya Province 13170, Thailand; e-mail: kulabtong2011@hotmail.com \\ 'Bureau of Conservation and Research, Zoological Park Organization under the Royal Patronage of His Majesty the King, Thailand; \\ e-mail: Rujira.ma@hotmail.com \\ "Corresponding author
}

\begin{abstract}
The feeding habit of the Asian water monitor, Varanus salvator (Laurenti, 1768) (Squamata Varanidae) in Thailand indicated that this species is carnivorous and scavenger. Here, we describe an observation of an Asian water monitor on an Asian toad, Duttaphrynus melanostictus (Schneider, 1799) (Anura Bufonidae) in urban areas of Central Thailand. Feeding habit data of an Asian water monitor is provided here.
\end{abstract}

KEY WORDS

Asian water monitor; Varanus salvator; Asian toad; Duttaphrynus melanostictus; ecology.

Received 15.06.2018; accepted 21.07.2018; printed 30.09.2018; published online 05.10.2018

\section{INTRODUCTION}

The Asian water monitor, Varanus salvator (Laurenti, 1768) (Squamata Varanidae) is the largest monitor in Thailand and the second largest lizard in the world (Shine et al., 1996). In Thailand, the Asian water monitor can be found in many ecosystems from hill streams, mangroves, national parks, to urban ecosystems. Habitat of this species is the semiaquatic ecosystem. The microhabitat of the species was thermally stable and the species also used burrows to control the body temperature (Shine et al., 1996). The Asian water monitor is the most widespread species among all monitor lizards. Distribution range of this species extends from India Subcontinental to South East Asia, Sunda Islands, and Moluccas (Böhme, 2003; Gaulke \& Horn 2004; Koch et al., 2007, 2010).
The current status of the species can be separated into following subspecies according to Koch et al. (2010). Namely, $V$. salvator salvator from Sri Lanka, V. salvator bivittatus (Kuhl, 1820) from Indonesia, type locality Java, $V$. salvator andamanensis Deraniyagala, 1944 from Andaman Islands, $V$. salvator macromaculatus Deraniyagala, 1944 from Thailand, Peninsula Malaysia, Vietnam, southern China, Hainan, Sumatra, and Borneo and smaller off-shore islands.

Feeding habit and reproductive biology of Asian water monitor were reported in many countries, especially in Sumatra, Indonesia. Shine et al. (1998) reported that the monitor lizard can eat a wide variety of prey, including vertebrates (e.g., rats, chickens) and invertebrates (e.g., insects, crabs). Fitzsimons \& Thomas (2016) reported that the Asian water monitor feeds on many types of car- 
casses such as the Bornean Bearded Pig, Sus barbatus barbatus Müller, 1838 (Mammalia Suidae) in Borneo, and the Banded pigs, Sus scrofa vittatus Boie, 1828 in Sumatra, Sus ahoenobarbus Huet, 1888 in Philippine (Gaulke, 1992), and food scraps from the rubbish bins of households and restaurants (Kulabtong \& Mahaprom, 2015).

The Asian water monitor, $V$. salvator, is carnivore and eats different types of food. They are known to eat fish, frogs, rodents, birds, crabs, snakes, turtles, young crocodiles, crocodile eggs, chickens, ducks, insects, carcasses, and garbage (Whitaker, 1981; Sprackland, 1992; Uyeda, 2009; Das, 2010). Reproduction of the monitor lizard occurs throughout the whole year, with lower intensity in drier months. The monitor lizard can produce multiple clutches of 6-17 eggs each year. In Thailand, the biological data of the Asian water monitor, $V$. salvator are poorly known, especially in the urban ecosystem.

\section{MATERIAL AND METHODS}

This study into the behavior of the Asian water monitor related to eating the Asian toad (Duttaphrynus melanostictus) was the first formal report in Thailand found at the Dusit Zoo in Bangkok, the Central region of Thailand. The area of the Dusit Zoo covers 22.7 hectares. This area is considered as the green area of the city ecological system of Bangkok. On 20 June, 2017, at 3.20 p.m., a newborn Asian water monitor was found. Its size, measured from the top of the head to the end of the tail, was of 30 centimeters. It was observed that while this water monitor was walking to find food at the nook of the floor cement, it held an Asian toad in its mouth up from such nook and then it managed to thrash the Asian toad back and forth, left and right down to the floor. This took about 3 minutes before it swallowed the toad.

\section{DISCUSSION AND CONCLUSIONS}

Regarding the biological aspects, in the family of Varanids, Pianka (1997) stated that the animal, when it is still young, tends to live in a tree rather than living on the floor because this would prevent it from being hunted. Then, when it is time to find

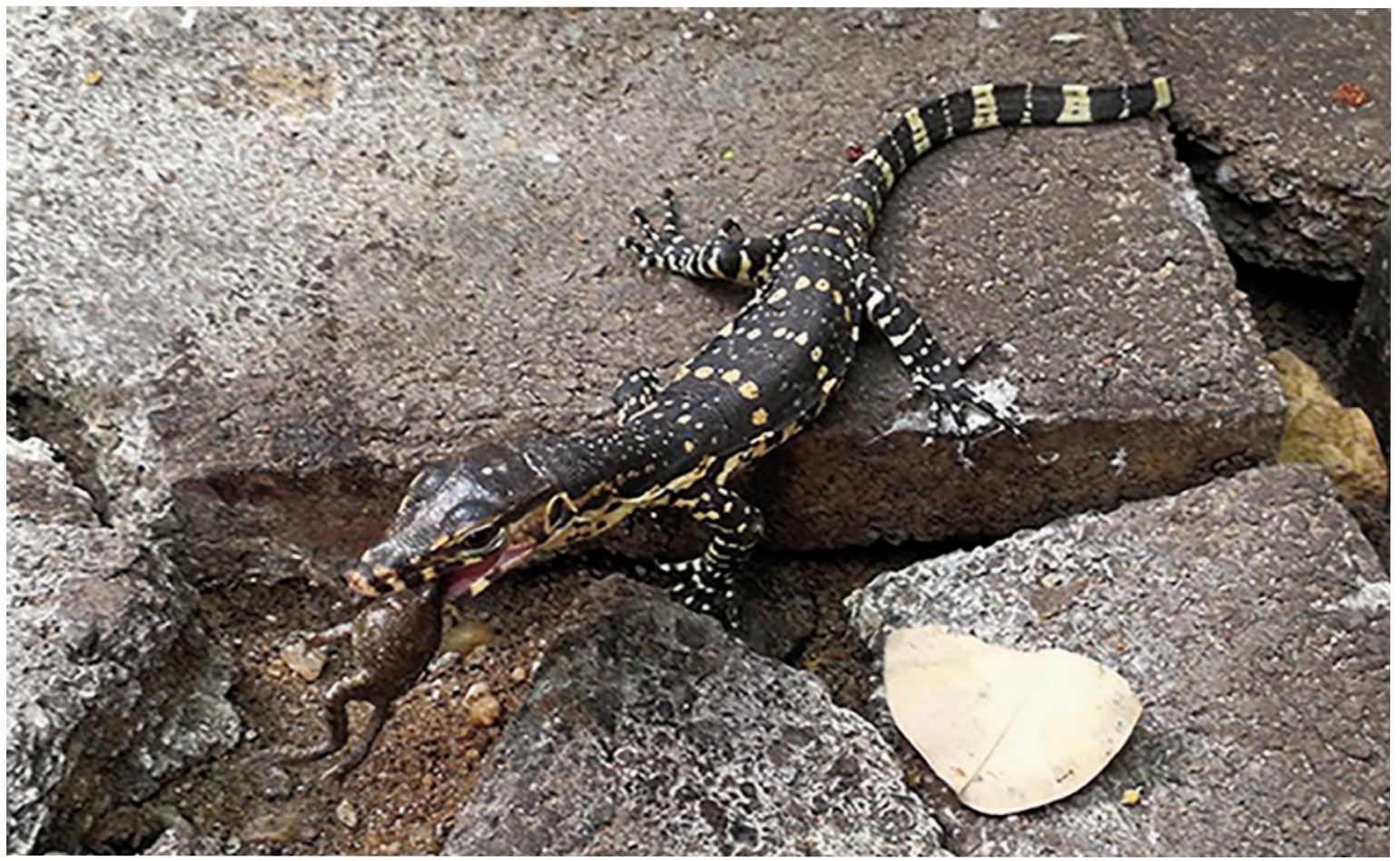

Figure 1. Asian water monitor, Varanus salvator (Laurenti, 1768) with captured Asian toad, Duttaphrynus melanostictus (Schneider, 1799). 
food, it would come down from the tree to the floor. The kinds of food of the young water monitor include young fish, young frog, young green frog, young worm. Therefore, the observation of the young water monitor eating a young toad is interesting because the water monitor has protein or enzymes that can resist toxin of the toad. There are also research reports of Karunarathna et al. (2017) and Whitaker (1981), reporting on the kinds of food of the water monitor and Bengal monitor living around the rain forest of Bangladesh and Sri Lanka and on the finding of the Bengal monitor (Varanus bengalensis) in Sri Lanka, eating toads the same way as in this study.

The body of the toad consists of paratoid glands, which look like the shape of an egg or an ellipse and are located behind the eyes. It produces a substance called "Bufotoxin", which looks like milk and smells pungent. In addition, its skin also releases several kinds of substances that have biological properties that could lead to high blood pressure, neurotoxicity, cardiotoxicity, haemolysis, and it can stimulate sleep (Dutta \& Das, 2013). It is reported that toad's toxin could irritate skin and had lead to illness and death of human beings in Laos and Taiwan eating these toads (Khan, 1982; Mercy, 1999).

\section{ACKNOWLEDGEMENTS}

We wish to thank the anonymous reviewers for their invaluable editorial advices. A very special thanks to Dr. Boripat Siriaroonrat, Bureau of conservation and research, under the Zoological Park Organization Thailand, for providing help during the field study and data support. Finally, we are grateful to all partners for their support.

\section{REFERENCES}

Böhme W., 2003. Checklist of the living monitor lizards of the world (family Varanidae). Zoologische Verhandeln, 341: 1-43.

Fitzsimons J. \& Thomas J., 2016. Feeding behavior of an Asian Water Monitor, Varanus salvator macromaculatus on a Bornean Bearded Pig, Sus barbatus barbatus Carcass. Biawak, 10: 48-50.

Das I., 2010. A field guide to the reptiles of South-East Asia: Myanmar, Thailand, Laos, Cambogia, Vietnam,
Peninsula Malaysia, Singapore, Sumatra, Borneo, Java, Bali. New Holland, London, 376 pp.

Dutta D. \& Das S.K., 2013. Phylogenetic relationship of Duttaphrynus melanostictus from India and China as revealed from the study of $12 \mathrm{~S}$ and $16 \mathrm{~S}$ mtDNA genes. International Journal of Zoological Research, 9: 49-57. DOI: 10.3923/ijzr.2013.49.57

Gaulke M., 1992. Taxonomy and biology of Philippine water monitors (Varanus salvator). Philippine Journal of Science, 121: 345-381.

Gaulke M. \& Horn H.G., 2004. Varanus salvator (Nominate form). In: Pianka E.R. \& King D.R. (Eds.): Varanoid lizards of the Word. Indiana University Press, Bloomington, Indianapolis, 244-257.

Karunarathna S.U., Surasinghe T., Dissanayake D., Boutejue M., Gabadage D. \& Madawala M., 2017. Dietary habits and the predators of the Bengal Monitor Varanus bengalensis in Sri Lanka. Biawak, 11: 28-39.

Khan M.S., 1982. Collection, preservation and identification of amphibian eggs from the plains of Pakistan. Pakistan Journal of Zoology, 14: 241-243.

Koch A., Auliya M., Schmitz A., Kuch U. \& Böhme W., 2007. Morphological Studies on the Systematics of South East Asian Water Monitors (Varanus salvator Complex): Nominotypic Populations and Taxonomic Overview. In: Horn H.-G., Böhme W. \& K r e b s U. (Eds.), Advances in Monitor Research III. Mertensiella 16, Rheinbach, 109-180.

Koch A., Auliya M. \& Ziegler T., 2010. Updated checklist of the living monitor lizards of the world (Squamata: Varanidae). Bonn Zoological Bullettin, 57: 127-136.

Kulabtong S. \& Mahaprom R., 2015. Observation on food items of Asian water monitor, Varanus salvator (Laurenti, 1768) (Squamata Varanidae), in urban ecosystem, Central Thailand. Biodiversity Journal, 6 : 695-698.

Mercy M., 1999. Studies on some aspects of the Biology and Ecology of the Common Indian Toad Bufo melanostictus Schneider (Class Amphibia, Order Anura). Thesis Mahatma Gandhi University. Department of Zoology, Mar Thoma College, Tiruvalla, Kerala.

Pianka E.R., 1997. Australia's thorny devil. Reptiles, 5: 14-23.

Shine R., Harlow P.S. \& Keogh J.S., 1996. Commercial harvesting of giant lizards: the biology of water monitors Varanus salvator in Southern Sumatra. Biological Conservation, 77: 125-134.

Shine R., Ambariyanto, Harlow P. \& Mumpuni, 1998. Ecological traits of commercially harvested water monitors, Varanus salvator, in northern Sumatra. Wildlife Research, 25: 437-447. 
Sprackland R.G., 1992. Giant lizards. Neptune, NJ: T.F.H. Publications, $61 \mathrm{pp}$

Uyeda L.T., 2009. Garbage appeal: relative abundance of Water Monitor Lizards (Varanus salvator) corre- lates with presence of human food leftovers on Tinijil Island, Indonesia. Biawak, 3: 9-17.

Whitaker R., 1981. Bangladesh - Monitors and turtles. Hamadryad, 6: 7-9. 